\title{
Advancing towards Better Cooperation for Better Sarcoma Prognoses
}

\author{
Javier Martín Broto \\ Department of Medical Oncology, HU Virgen del Rocio, Sevilla, Spain
}

\begin{abstract}
Keywords
International collaboration - Multidisciplinary teams .

National sarcoma networks · Spanish Group for Research

on Sarcomas
\end{abstract}

\begin{abstract}
Multidisciplinary teams (MDTs) are necessary to deliver the best sarcoma care. Planning the optimal therapeutic strategy per patient requires input and expertise from several disciplines. Case/cohort studies have reported improved patient outcomes associated with treatment by MDTs and/or treatment in sarcoma centres. Many countries have established national networks of sarcoma reference centres and most have developed evidence-based clinical practice guidelines agreed using multidisciplinary expertise. In many countries, sarcoma networks are organised as cooperative groups. These groups are committed to delivering continuing medical education and are open to collaboration with other groups. Among their many benefits, cooperative groups have huge capacity for accrual, which is essential for rare cancers such as sarcoma. Since its beginnings in 1994 with a small core of oncologists focussing on soft tissue sarcoma, the Spanish Group for Research on Sarcomas (GEIS) has expanded to 376 members from more than 10 disciplines (as at June 2017). GEIS is currently actively collaborat-
\end{abstract}

\section{KARGER}

() 2018 S. Karger AG, Basel

E-Mail karger@karger.com

www.karger.com/ocl ing with several international cooperative groups. As MDTs are essential to offer the best outcome in sarcoma care, and international cooperation between sarcoma groups is essential to address the many unanswered questions in sarcoma management, both approaches should be made mandatory.

C 2018 S. Karger AG, Basel

\section{Multidisciplinary Teams in Sarcoma}

There is general agreement that multidisciplinary teams (MDTs) are necessary to deliver the best care in treating sarcomas, even in the absence of supporting level I/IIA evidence. Although the sarcoma community has a strong conviction that MDTs are important for patient care, in actual practice, there are still self-sufficient conducts and it is often difficult for patients to navigate around the various compartments of multidisciplinary care, resulting in lack of overall perspective, forward planning, and treatment synchronicity. Ultimately, patients encounter the consequences due to a higher risk of local recurrence and, in someinstances, metastatic spread. Instead, patients should be at the centre of multidisciplinary care with the MDT orbiting around the patient and defining each situation and each treatment plan.

\footnotetext{
Dr. Javier Martín Broto

Department of Medical Oncology, HU Virgen del Rocio

Av. Manuel Siurot, s/n

ES-41013 Sevilla (Spain)

E-Mail jmartin@ mustbesevilla.org
} 
Table 1. Case/cohort studies examining outcomes associated with treatment by multidisciplinary teams and/or specialist sarcoma centres

\begin{tabular}{|c|c|c|c|c|c|}
\hline Reference & Year & Objectives & Number & Results & Comments \\
\hline [9] & 2004 & $\begin{array}{l}\text { Sarcoma centre versus general } \\
\text { hospital }\end{array}$ & 263 & $\begin{array}{l}\text { 5-year RFS: } 39 \text { vs. } 19 \% \\
\text { 5-year OS: HR } 0.59 \text { for high- } \\
\text { grade tumours }\end{array}$ & $\begin{array}{l}\text { Centralisation improves } \\
\text { local control in all } \\
\text { patients and OS in some } \\
\text { patients }\end{array}$ \\
\hline$[10]$ & 2002 & $\begin{array}{l}\text { To express the magnitude of } \\
\text { institutional experience in the } \\
\text { treatment of STSE cases as a } \\
\text { surrogate measure of } \\
\text { specialized expertise }\end{array}$ & 1,467 & $\begin{array}{l}\text { Higher risk of death (OR 1.4) } \\
\text { and amputation (OR 3.5) if } \\
\text { patient not treated in sarcoma } \\
\text { centre within } 3 \text { months of } \\
\text { diagnosis }\end{array}$ & $\begin{array}{l}\text { Advisable to refer } \\
\text { patients with STS of the } \\
\text { extremities within the } \\
\text { first } 3 \text { months }\end{array}$ \\
\hline [5] & 2004 & $\begin{array}{l}\text { To assess the conformity of } \\
\text { medical practice to clinical } \\
\text { practice guidelines }\end{array}$ & 100 & $\begin{array}{l}\text { Presurgery MDT discussion and } \\
\text { management in sarcoma centre } \\
\text { predicted conformity to } \\
\text { guidelines and better local } \\
\text { control }\end{array}$ & $\begin{array}{l}\text { Treatment strategy } \\
\text { within MDT improves } \\
\text { clinical outcomes }\end{array}$ \\
\hline [12] & 1996 & $\begin{array}{l}\text { Compare results after versus } \\
\text { before implementation of } \\
\text { MDT for STS (single } \\
\text { institution) }\end{array}$ & 134 & $\begin{array}{l}\text { LR: } 13 \text { vs. } 48 \% \\
\text { DFS: } 69 \text { vs. } 36 \%\end{array}$ & $\begin{array}{l}\text { Implementation of a } \\
\text { MDT can improve } \\
\text { outcomes }\end{array}$ \\
\hline$[13,14]$ & 2000 & $\begin{array}{l}\text { Survival analyses in specialist } \\
\text { bone centre versus paediatric } \\
\text { oncology network versus non- } \\
\text { teaching hospital }\end{array}$ & $\begin{array}{l}\text { 1,267 Osteo } \\
831 \text { Ewing's }\end{array}$ & $\begin{array}{l}\text { Osteosarcoma RR }(95 \% \text { CI): } \\
\text { BTS } 1 \text { (reference) } \\
\text { UKCCSG } 0.72(0.57-0.92) \\
\text { Other } 1.10(0.90-1.34) \\
\text { NTH } 1.33(1.03-1.71) \\
\text { Unknown } 1.15(0.83-1.59)\end{array}$ & $\begin{array}{l}\text { Centralisation in } \\
\text { paediatric oncology } \\
\text { centres or bone tumour } \\
\text { centres better than non- } \\
\text { teaching hospital }\end{array}$ \\
\hline
\end{tabular}

BTS, bone tumour service; CT, chemotherapy; DFS, disease-free survival; Ewing's, Ewing's sarcoma; HR, hazard ratio; LR, local recurrence; MDT, multidisciplinary team; MRI, magnetic resonance imaging; NTH, non-teaching hospital; OS, overall survival; Osteo, osteosarcoma; RFS, relapse-free survival; RR, relative risk; STS, soft tissue sarcoma; STSE, soft tissue sarcoma of the extremities; UKCCSG, United Kingdom Children's Cancer Study Group.

In patients with localised soft tissue sarcoma (STS), surgery is the therapeutic mainstay; adequate biopsy and a MDT are the first steps towards a good surgical outcome. Many decisions need to be shared at multidisciplinary tumour board: Is the tumour resectable? What is the local recurrence risk? What is the patient's condition? What are the implications for limb function? What is the distant metastatic risk? What might be the long-term effects of surgery? Planning the optimal therapeutic strategy per patient requires input and expertise from several disciplines.

\section{Reference Centres}

Numerous publications have argued the necessity of having MDTs to achieve a successful outcome in sarcoma care [1-8]. Interesting evidence also derives from case/cohort studies, some of which involved $>1,000 \mathrm{pa}-$ tients (Table 1) [5, 9-14]. Bhangu et al. [9] (UK) reported differences in outcomes between specialist centres and general hospitals for patients with STS. Compared with non-specialised centres, centralisation significantly improved local control in all patients and overall survival in some patients. Paszat et al. [10] (Canada) analysed the effect of time of referral to a specialised sarcoma centre 
Table 2. Examples of clinical guidelines in sarcoma care

\begin{tabular}{|c|c|c|}
\hline Country & Guidelines & Availability \\
\hline $\begin{array}{l}\text { France: French Federation of } \\
\text { Comprehensive Cancer Centers }\end{array}$ & $\begin{array}{l}\text { Management of adult patients with } \\
\text { soft tissue sarcoma (STS), uterine } \\
\text { sarcoma or gastrointestinal stromal } \\
\text { tumours (GIST) }\end{array}$ & $\begin{array}{l}\text { Developed initially in } 1995 \\
\text { Most recent revision in } 2006\end{array}$ \\
\hline The Netherlands & Diagnosis and treatment of STS & $\begin{array}{l}\text { Developed initially in } 1983 \\
\text { Approved nationwide in } 1993\end{array}$ \\
\hline $\begin{array}{l}\text { United Kingdom: National Institute for } \\
\text { Health and Care Excellence }\end{array}$ & $\begin{array}{l}\text { Improving outcomes for people } \\
\text { with sarcoma }\end{array}$ & $2006[5]$ \\
\hline $\begin{array}{l}\text { Scandinavia: Scandinavian Sarcoma } \\
\text { Group }\end{array}$ & $\begin{array}{l}\text { Recommendations for } \\
\text { radiotherapy in bone and STS }\end{array}$ & $\begin{array}{l}\text { Developed initially in } 1979 \\
\text { Most recent revision in } 2006 \text { (http://www.ssg-org.net/wp-content/ } \\
\text { uploads/2011/05/SSG-RT-Guidelines-December-2015.pdf) }\end{array}$ \\
\hline $\begin{array}{l}\text { Spain: Spanish Group for Research on } \\
\text { Sarcomas }\end{array}$ & $\begin{array}{l}\text { Management of GIST } \\
\text { Diagnosis and treatment of STS } \\
\text { Diagnosis, treatment and follow- } \\
\text { up of malignant bone tumours } \\
\text { (other than Ewing's) }\end{array}$ & $\begin{array}{l}2017[16] \\
2016[17] \\
2017[18]\end{array}$ \\
\hline $\begin{array}{l}\text { Australia: Cancer Council Australia } \\
\text { Sarcoma Guidelines Working Party }\end{array}$ & $\begin{array}{l}\text { Management of adult onset } \\
\text { sarcoma }\end{array}$ & $\begin{array}{l}2014 \\
\text { (https://wiki.cancer.org.au/australia/Guidelines:Sarcoma) }\end{array}$ \\
\hline $\begin{array}{l}\text { USA: National Comprehensive Cancer } \\
\text { Network }\end{array}$ & STS, version 2.2018 & 2018 (https://www.nccn.org/professionals/physician_gls/default.aspx) \\
\hline
\end{tabular}

on outcome for patients with STS of the extremities. Patients who were not referred to a specialised sarcoma centre within the first 3 months had a threefold greater risk of amputation and a 1.4-fold greater risk of death compared with those who had been referred [10]. RayCoquard et al. [5] (France) analysed the relationship between conformity to clinical practice guidelines and treatment outcomes in STS. Closer compliance with guidelines by specialised versus local centres was associated with improved outcomes [5]. Using the Scandinavian Registry, Bauer et al. [11] (Sweden) found that greater ordering of pre-surgical clinical tests by specialised sarcoma centres was associated with improved outcomes. Wiklund et al. [12] (Finland) reported improved outcomes at a single hospital after versus before implementation of a MDT. Lastly, a study by Stiller et al. [13] (UK) found that survival rates in patients with osteosarcoma or Ewing's sarcoma treated in specialist bone tumour treatment centres or paediatric oncology centres were superior to those of patients treated in non-teaching hospitals $[13,14]$.

Collectively, these studies provide strong support for the implementation of MDTs to improve outcomes in sarcoma patients. Moreover, a retrospective analysis of 219 patients with sarcoma treated at specialised centres in France and Italy found that clinicians' adherence to clin-

Advancing towards Better Cooperation

for Better Sarcoma Prognoses ical practice guidelines was cost-effective in terms of total treatment costs and relapse-free survival (both were less costly and more effective) [15].

\section{National Networks}

During the implementation of national networks of sarcoma reference centres, the first objective of many countries was to define clinical guidelines in sarcoma care (Table 2) [5, 16-18]. Across all regions, evidence-based guidelines were adapted for health organisations at the national level, and were agreed using multidisciplinary expertise.

In many countries, sarcoma networks are organised as cooperative groups. All networks actively deliver continuing medical education and are open to collaboration with other groups.

The Italian Sarcoma Group (ISG, www.italiansarcomagroup.org) has a long history of referral based on the quality of the professionals and outcomes. The ISG has huge capacity for accrual, is active in numerous histologies including some rare sarcoma subtypes, and embraces collaboration with other groups.

The French Federation of Cancer Centers Sarcoma Group (FNCLCC, www.fondationarcad.org/espace- 


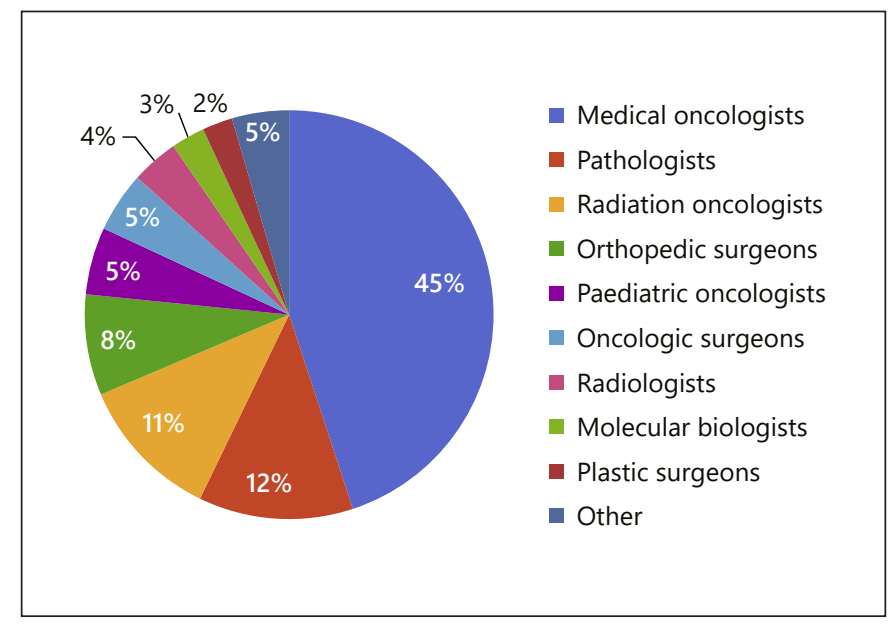

Fig. 1. Membership of the Spanish Group for Research on Sarcomas (GEIS, www.grupogeis.org/en) by speciality: 376 members as at June 2017.

partenaires/acteurs-de-la-lutte-contre-le-cancer/fnclcc) has a long history of networking. Their pathology network is a model system, responsible for development of the widely-used pathology grading system. Currently, all pathological diagnoses in France are peer reviewed by 2 pathologists. The FNCLCC were also pioneers in establishing the peer-review process.

The Scandinavian Sarcoma Group (SSG, www.ssgorg.net) has a long history of referral based on law, and serves as a model for using the population-based registry as a tool for quality improvement in sarcoma.

The German Interdisciplinary Sarcoma Group (GISG, www.gisg.de/index.php/studien.html) is relatively young and is profiting from the experience of other networks by having implemented MDT at the outset. The GISG has a potentially huge capacity for accrual, especially in gastrointestinal stromal tumour.

In the United States, the Sarcoma Alliance for Research Through Collaboration (SARC, https://sarctrials. org) has a huge capacity for accrual and offers open educational meetings through the Connective Tissue Oncology Society or American Society of Clinical Oncology to develop young investigators.

In Spain, the Ministry of Health has defined criteria that institutions must have to be accredited as a national sarcoma centre:

- The sarcoma unit should include surgeons, medical oncologists, radiation therapists, pathologists, and radiologists

- The MDT must meet at least weekly
- The number of new cases per year that must be reviewed and treated in committee is $>70$ for STS, $>10$ for osteosarcoma, and $>10$ for retroperitoneal sarcoma

- The institution should be accredited as a research institute with active research call applications

- The institution must provide official postgraduate programs.

As at February 2018, there were 5 accredited centres in Spain, and 2 applications were under consideration.

The Spanish Group for Research on Sarcomas (GEIS, http://www.grupogeis.org/en) began in 1994 as a small core team of sarcoma oncologists. By 2000, the group had expanded to 150 members with a continued general focus on STS. Over the next decade, several other specialities came on board. By 2011, GEIS had 270 multidisciplinary members and a broad focus on all types and locations of sarcoma. As at June 2017, there were 376 members representing medical oncology (45\%), pathology (12\%), radiation oncology (11\%), orthopaedic surgery $(8 \%)$ and several other disciplines (Fig. 1).

A GEIS observational study that examined outcomes in approximately 700 patients with STS showed that cases managed in defined specialist centres had significantly better outcomes in terms of overall survival than cases managed in local hospitals $(p=0.003)$. The greater likelihood of specialised centres to prescribe peri-operative chemotherapy in high-risk patients with localised sarcoma was associated with significantly prolonged relapsefree survival $(p=0.011)$. Even in the metastatic setting, cases managed by specialist centres had better overall survival compared to local hospitals $(p=0.036)$ [19].

\section{International Cooperation: Facing Ambitious New Goals}

Currently, there are several trials underway that GEIS is conducting in conjunction with the Italian Sarcoma Group, French Sarcoma Group, Scandinavian Sarcoma Group, German Sarcoma Group, and European Organisation for Research and Treatment of Cancer. Collaboration with SARC and the Australasian Sarcoma Group in anticipated in future.

Although international collaborations are more difficult to arrange than undertaking research domestically, they are essential and ultimately more productive. As an example, international cooperation can dramatically improve the accrual rate. In the GEIS-32 phase II trial of the French, Italian and Spanish Sarcoma Groups, 48 patients with solitary fibrous tumour and 26 patients with ex- 
traskeletal myxoid chondrosarcoma (both extremely rare tumours) were accrued in 2 years (ClinicalTrials.gov Identifier: NCT02066285) [20]. In the ISG-GEIS 1001 phase III trial, 435 patients with STS were accrued in 4 years owing to cooperation between France, Italy, Poland and Spain [21].

To ensure data quality in international collaborations, processes that need to be implemented include central review (pathologic and radiologic), an independent data monitoring committee, an electronic data case report form (with tracking), imaging platforms and accompanying translational studies.

Challenges for the future include improving integration among the various national cooperative groups and developing international collaborative clinical guidelines for sarcoma. The European Reference Networks/European network for Rare adult solid Cancer (ERN-EURACAN, euracan.ern-net.eu) is a new cooperative group with members located in 17 European countries as at September 2018. New collaborative projects are expected to be developed within this framework. Although the best model for international collaboration is yet to be identified, the Gynecological Cancer Intergroup (GCIG, https:// gciggroup.com/) model may be appropriate for sarcoma. Supranational governance will be required to answer many open questions in sarcoma care.

\section{Conclusions}

MDTs are a core element for sarcoma care. National referral circuits and networks have a central role in improving outcomes for sarcoma patients. Compliance with clinical practice guidelines should be continuously evaluated in view of the positive impact on patient outcomes. International cooperation between sarcoma groups is essential to address the many unanswered questions in sarcoma management and should be mandatory.

\section{Acknowledgements}

Writing assistance was provided by Content Ed Net (Madrid, Spain) with funding from PharmaMar, Madrid, Spain.

\section{Disclosure Statement}

J.M.B. has received speakers' bureau from PharmaMar; has received research funding from Eisai, Novartis, and PharmaMar; has served in a consulting or advisory role for Amgen, Bayer, GSK, Lilly, Novartis, and PharmaMar. The author has no other relevant affiliations or financial involvement with any organization or entity with a financial interest in or financial conflict with the subject matter or materials discussed in the manuscript apart from those disclosed.

\section{References}

1 Rydholm A. Improving the management of soft tissue sarcoma. Diagnosis and treatment should be given in specialist centres. BMJ. 1998 Jul;317(7151):93-4.

2 Trovik CS, Gustafson P, Bauer HC, Saeter G, Klepp R, Berlin O, et al. Consequences of local recurrence of soft tissue sarcoma: 205 patients from the Scandinavian Sarcoma Group Register. Acta Orthop Scand. 2000 Oct;71(5): 488-95.

3 Mankin HJ, Mankin CJ, Simon MA; Members of the Musculoskeletal Tumor Society. The hazards of the biopsy, revisited. J Bone Joint Surg Am. 1996 May;78(5):656-63.

4 Hoeber I, Spillane AJ, Fisher C, Thomas JM. Accuracy of biopsy techniques for limb and limb girdle soft tissue tumors. Ann Surg Oncol. 2001 Jan-Feb;8(1):80-7.

5 Ray-Coquard I, Thiesse P, Ranchère-Vince D, Chauvin F, Bobin JY, Sunyach MP, et al. Conformity to clinical practice guidelines, multidisciplinary management and outcome of treatment for soft tissue sarcomas. Ann Oncol. 2004 Feb;15(2):307-15.

Advancing towards Better Cooperation for Better Sarcoma Prognoses
6 National Institute for Health and Care Excellence (NICE). Improving Outcomes for People with Sarcoma: The Manual. 2006 [Accessed 27 September 2018]. Available from: https://www.nice.org.uk/guidance/csg9/resources/improving-outcomes-for-peoplewith-sarcoma-update-773381485.

7 Shah A, Botchu R, Ashford RU, Rennie WJ. Diagnostic triage for sarcoma: an effective model for reducing referrals to the sarcoma multidisciplinary team. Br J Radiol. 2015 May;88(1049):20150037.

8 Siegel GW, Biermann JS, Chugh R, Jacobson JA, Lucas D, Feng M, et al. The multidisciplinary management of bone and soft tissue sarcoma: an essential organizational framework. J Multidiscip Healthc. 2015 Feb;8:10915.

9 Bhangu AA, Beard JA, Grimer RJ. Should soft tissue sarcomas be treated at a specialist centre? Sarcoma. 2004;8(1):1-6.

10 Paszat L, O'Sullivan B, Bell R, Bramwell V, Groome P, Mackillop W, et al. Processes and outcomes of care for soft tissue sarcoma of the extremities. Sarcoma. 2002;6(1):19-26.
11 Bauer HC, Trovik CS, Alvegård TA, Berlin O, Erlanson M, Gustafson P, et al. Monitoring referral and treatment in soft tissue sarcoma: study based on 1,851 patients from the Scandinavian Sarcoma Group Register. Acta Orthop Scand. 2001 Apr;72(2):150-9.

12 Wiklund T, Huuhtanen R, Blomqvist C, Tukiainen E, Virolainen M, Virkkunen P, et al. The importance of a multidisciplinary group in the treatment of soft tissue sarcomas. Eur J Cancer. 1996 Feb;32A(2):269-73.

13 Stiller CA, Passmore SJ, Brownbill PA. Patterns of care and survival for patients with bone sarcoma. Report. Project NCP/E16. NHS National Cancer Research and Development Programme. 2000.

14 National Institute for Health and Care Excellence (NICE). Improving Outcomes for People with Sarcoma: The Evidence Review. 2006 [Accessed 27 September 2018]. Available from: https://www.nice.org.uk/guidance/ csg9/documents/evidence-review. 
15 Perrier L, Buja A, Mastrangelo G, Vecchiato $\mathrm{A}$, Sandonà $\mathrm{P}$, Ducimetière $\mathrm{F}$, et al. Clinicians' adherence versus non adherence to practice guidelines in the management of patients with sarcoma: a cost-effectiveness assessment in two European regions. BMC Health Serv Res. 2012 Mar; 12(1):82.

16 Poveda A, García Del Muro X, López-Guerrero JA, Cubedo R, Martínez V, Romero I, et al.; GEIS (Grupo Español de Investigación en Sarcomas/Spanish Group for Sarcoma Research). GEIS guidelines for gastrointestinal sarcomas (GIST). Cancer Treat Rev. 2017 Apr;55:107-19.
17 Garcia del Muro X, de Alava E, Artigas V, Bague S, Braña A, Cubedo R, et al.; Spanish Group for Research on Sarcoma. Clinical practice guidelines for the diagnosis and treatment of patients with soft tissue sarcoma by the Spanish group for research in sarcomas (GEIS). Cancer Chemother Pharmacol. 2016 Jan;77(1):133-46.

18 Redondo A, Bagué S, Bernabeu D, Ortiz-Cruz E, Valverde C, Alvarez R, et al. Malignant bone tumors (other than Ewing's): clinical practice guidelines for diagnosis, treatment and follow-up by Spanish Group for Research on Sarcomas (GEIS). Cancer Chemother Pharmacol. 2017 Dec;80(6):1113-31.

19 Martin-Broto J, Hindi N, Cruz J, et al. Relevance of reference centers in sarcoma care and quality item evaluation: results from the prospective registry of the Spanish Group for Research in Sarcoma (GEIS). Oncologist. 2018. Epub ahead of print.
20 ClinicalTrials.gov. A phase II open-label trial of pazopanib administered as a single agent in patients with unresectable or metastatic solitary fibrous tumor (SFT) and extraskeletal myxoid chondrosarcoma (EMC). [Accessed 27 September 2018]. Available from: https:// clinicaltrials.gov/ct2/show/NCT02066285.

21 Gronchi A, Ferrari S, Quagliuolo V, Broto JM, Pousa AL, Grignani G, et al. Histotype-tailored neoadjuvant chemotherapy versus standard chemotherapy in patients with high-risk soft-tissue sarcomas (ISG-STS 1001): an international, open-label, randomised, controlled, phase 3, multicentre trial. Lancet Oncol. 2017 Jun;18(6):812-22. 